Gut, 1983, 24, 94-98

\title{
Clostridium difficile toxin-induced intestinal secretion in rabbit ileum in vitro
}

\author{
S HUGHES, G WARHURST, L A TURNBERG, ${ }^{*} \mathrm{~N}$ B HIGGS, \\ L G GIUGLIANO, AND B S DRASAR
}

From the Department of Medicine, Hope Hospital, Salford, and Department of Microbiology, London School of Hygiene and Tropical Medicine, London

SUMmaRy In rabbit ileum in vitro Clostridium difficile toxin (200 $\mu$ l crude extract) almost abolished net $\mathrm{Na}$ absorption, by decreasing mucosa to serosa flux, and induced net $\mathrm{Cl}$ secretion by increasing the serosa to mucosa flux. These flux changes were induced when there was no visible histological damage to the mucosa. The toxin did not influence adenylate or guanylate cyclase activity in a plasma membrane fraction of isolated rabbit enterocytes nor did it affect cAMP concentrations in intact rabbit ileum pre-incubated with toxin. The flux responses to the toxin were prevented by removing calcium from the serosal medium, suggesting that the secretory process may be calcium dependent. These results indicate a possible mechanism by which this toxin could induce diarrhoea.

Clostridium difficile toxin has been implicated as an important cause of antibiotic-associated colitis. ${ }^{12}$ Although the toxin damages the colonic epithelium ${ }^{3}$ and has cytotoxic effects in tissue culture, ${ }^{+}$watery diarrhoea is a common feature of the disease in many cases when mucosal damage is inapparent..$^{5}$ We have, therefore, investigated the effect of a crude toxin on intestinal transport in isolated rabbit ileum to elucidate whether it can act as an intestinal secretagogue.

\section{Methods}

TOXIN PREPARATION

Toxigenic $\mathrm{Cl}$ difficile was grown in Oxoid cooked meat medium at $37^{\circ} \mathrm{C}$ for five days. The cultures were centrifuged and the supernatant filtered through a $0.22 \mu$ membrane filter (Millipore Corporation, Bedford. Mass.) and stored at $-70^{\circ} \mathrm{C}$ until used. The cytotoxicity of this material was confirmed using tissue culture methods. ${ }^{6}$ Other workers have recently separated $\mathrm{Cl}$ difficile toxin into fractions containing an enterotoxin and a cytotoxin. ${ }^{7}$ Thus it is likely that our crude extract contained more than one toxin. Control medium

* Address for correspondence: Professor L A Turnberg. Department of Medicine. Hope Hospital. (University of Manchester. School of Medicine). Eccles Old Road. Salford M6 8HD.

Received for publication 17 May 1982 was prepared as above using non-toxigenic $\mathrm{Cl}$ difficile.

ION TRANSPORT STUDIES

These were performed as previously described. ${ }^{8}$ Briefly, male New Zealand white rabbits $(2-4 \mathrm{~kg}$ weight) were killed by air embolus and the distal ileum rapidly removed and bathed in oxygenated Ringer's bicarbonate buffer solution. Sections of the tissue were stripped of muscle layers and mounted in a modified Ussing chamber. ${ }^{9}$ The tissue was bathed on each side by $10 \mathrm{ml}$ of isotonic buffer solution of composition $\mathrm{Na} 146, \mathrm{~K} 4 \cdot 2, \mathrm{Cl} 125 \cdot 8, \mathrm{HCO}_{3} 26 \cdot 6$, Ca $1 \cdot 2, \mathrm{H}_{2} \mathrm{PO}_{4} 0 \cdot 2, \mathrm{HPO}_{4} 1 \cdot 2, \mathrm{Mg} 1 \cdot 2$, glucose 10 $\mathrm{mmol} / \mathrm{l}$, and $\mathrm{pH} 7 \cdot 4$. When investigating the effect of calcium on secretion a calcium-free buffer solution with a calcium-chelating agent was placed on the serosal side $\left(\mathrm{Na} 146, \mathrm{~K} 4 \cdot 2, \mathrm{Cl} 125 \cdot 8, \mathrm{HCO}_{3} 26 \cdot 6\right.$, $\mathrm{H}_{2} \mathrm{PO}_{4} 0 \cdot 2, \mathrm{HPO}_{4} 1 \cdot 2, \mathrm{Mg} 1 \cdot 2$, ethylene glycol-bis$\left(\beta\right.$-amino ethyl ether) $\mathrm{N}, \mathrm{N}^{1}$-tetraacetic acid (EGTA) $0 \cdot 2$, glucose $10 \mathrm{mmol} / 1$, and $\mathrm{pH} 7 \cdot 4$ ). The buffer solution was stirred and oxygenated via a bubble lift mechanism by a $95 \% \quad \mathrm{O}_{2} / 5 \% \quad \mathrm{CO}_{2}$ mixture and maintained at $37^{\circ} \mathrm{C}$.

The transmucosal potential difference (PD) was measured as previously described ${ }^{8}$ and the shortcircuit current (Isc) by means of a voltage clamp. Tissue resistance was calculated from PD and Isc. Sodium and chloride fluxes were measured using 0.5 
$\mu \mathrm{Ci}^{22} \mathrm{Na}$ and $2 \cdot 5 \mu \mathrm{Ci}^{36} \mathrm{Cl}$ (Radiochemical Centre, Amersham) added to either mucosal or serosal reservoirs. After a 20 minute equilibration period serial $1 \mathrm{ml}$ samples were taken at 20 minute intervals and this volume was replaced with unlabelled buffer solution. Eight tissues from one rabbit were mounted in each experiment and these were paired provided that their resistances differed by less than $25 \%$. Unidirectional fluxes were used to calculate a net flux for each tissue pair and these fluxes and residual ion flux were calculated as described previously. ${ }^{8}$ After a 20 minute control flux period $200 \mu$ l of toxin-containing medium was added to the mucosal chamber and left in contact with the tissue for 40 minutes before three consecutive 20 minute flux determinations were carried out. Two hundred microlitres of control medium (without toxin) was added to paired control tissues and flux measurements carried out as for the toxin-treated tissues. After the experiments tissues were carefully removed, fixed with $2.5 \%$ glutaraldehyde in cacodylate buffer, and post-fixed with $2 \%$ osmium tetroxide. The tissue was dehydrated, embedded in expoxy resin, and $1 \mu$ sections were stained with toluidine blue for examination by light microscopy.

\section{CYCLIC NUCLEOTIDE STUDIES}

\section{1 cAMP}

Pieces of stripped rabbit ileal mucosa were placed in flasks containing $10 \mathrm{ml}$ of buffer solution (as above) oxygenated with $95 \% \mathrm{O}_{2} 5 \% \mathrm{CO}_{2}$, and incubated at $37^{\circ} \mathrm{C}$. After a 45 -minute pre-incubation period $\mathrm{Cl}$ difficile toxin $(200 \mu \mathrm{l})$ was added. Control flasks contained $200 \mu$ l of culture medium. At 45 and 90 minutes after addition the mucosal pieces were removed and placed immediately in absolute ethanol at $-40^{\circ} \mathrm{C}$ containing $4 \mathrm{nCi}\left({ }^{3} \mathrm{H}\right)$ cAMP as a recovery marker. Tissues were homogenised with a motor driven Teflon pestle and centrifuged at $2500 \mathrm{~g}$ for 20 minutes. The resulting supernatants were dried under $\mathrm{N}_{2}$ at $40^{\circ} \mathrm{C}$ and suspended in a buffer containing Tris- $\mathrm{HCl} 50 \mathrm{mmol} / \mathrm{l}$ and ethylene diamine tetraacetic acid (EDTA) $4 \mathrm{mmol} / \mathrm{l} \mathrm{pH} \mathrm{7 \cdot 4}$. Aliquots were assayed for cAMP using a commercial kit (Radiochemical Centre, Amersham). The precipitate recovered after centrifugation was dissolved in $1 \mathrm{~N} \mathrm{NaOH}$ and assayed for protein. ${ }^{10}$ Results were expressed as picomoles of cAMP per milligram of protein.

\section{Effect of Clostridium toxin on nucleotide cyclases}

A semi-purified plasma membrane fraction was prepared from isolated rabbit small intestinal epithelial cells according to the method of Murer et al. ${ }^{11}$ The final membrane pellet was resuspended in Ringer's bicarbonate buffer and stored at $-70^{\circ} \mathrm{C}$ until use.
Adenylate cyclase assays were performed according to the method of Amiranoff et al. ${ }^{12}$ The reaction mixture contained $0.8 \mathrm{mmol} / \mathrm{l}$ adenosine triphosphate (ATP); $10 \mathrm{mmol} / \mathrm{MgCl} 2 ; 1 \mathrm{mmol} / \mathrm{l}$ EDTA; $0.2 \mathrm{mmol} / 1$ 3-isobutyl-1-methyl-xanthine (IBMX); $20 \mathrm{mmol} / \mathrm{l}$ creatinine phosphate; $25 \mathrm{mmol} / \mathrm{l}$ Tris; $4 \mathrm{mg} / \mathrm{ml}$ bovine serum albumin; $1 \mathrm{mg} / \mathrm{ml}$ phosphocreatine kinase and 50-100 $\mu \mathrm{g}$ membrane protein in a final volume of $250 \mu$ l. Incubations were performed at $30^{\circ} \mathrm{C}$ for periods of up to one hour and the reaction stopped by heating to $100^{\circ} \mathrm{C}$ for three minutes. cAMP ws determined with the assay kit. Guanylate cyclase was determined in a similar way except that the reaction mixture contained $1 \mathrm{mmol} / \mathrm{l}$ guanosine triphosphate (GTP); $10 \mathrm{mmol} / \mathrm{l}$ caffeine; $5.35 \mathrm{mmol} / 1 \mathrm{MnCl}_{2}$ creatine phosphate; $1 \mathrm{mg} / \mathrm{ml}$ creatinine phosphokinase; $40 \mathrm{mmol} / \mathrm{l}$ Tris- $\mathrm{HCl}, \mathrm{pH}$ $7 \cdot 4$; and $10-15 \mu \mathrm{g}$ membrane protein. The cGMP produced was assayed by a specific radioimmunoassay (Radiochemical Centre, Amersham).

Both assays were started by the addition of membrane protein. Toxin and control medium were added to the incubations immediately before the addition of the membranes in a volume of $5 \mu$ l. Results are expressed as picomoles of cyclic nucleotides formed per milligram of protein.

All results are expressed as the mean \pm 1 SEM. Statistical comparisons were performed using Student's $t$-test for paired variables and considered significant if $p<0.05$. An analysis of variance was also performed for some of the data comparisons.

\section{Results}

The addition of $200 \mu \mathrm{l}$ of toxin-containing medium caused a slow but significant rise in potential difference $(10.9 \%$ at 60 minutes and $22.9 \%$ at 100 minutes, $\mathrm{p}<0.02)$ and short circuit current $(21.2 \%$ at 60 minutes and $36.5 \%$ at 100 minutes, $\mathrm{p}<0.01$ ) and $a$ fall in tissue resistance $(R)(7.8 \%$ at 60 minutes and $9.5 \%$ at 100 minutes, $\mathrm{p}<0.02, \mathrm{n}=15$ ). The control medium, however, caused similar but smaller changes in short circuit current and tissue resistance and an analysis of variance showed that there was no significant difference between the responses to control and toxin-containing medium.

The control medium had no significant effect on unidirectional fluxes over a period of 100 minutes but the toxin-containing medium almost abolished net sodium absorption, mainly by decreasing the mucosa to serosa flux, and induced net chloride secretion mainly by increasing the serosa to mucosa flux. Significant changes were able to be seen at 40 to 60 minutes after exposure but were maximal at 80 to 100 minutes. The residual ion flux $\left(J^{R}\right.$ net) was unaffected (Table 1). Analysis of variance 
Table 1 Effect of $\mathrm{Cl}$ difficile toxin on unidirectional and net $\mathrm{Na}$ and $\mathrm{Cl}$ fluxes over 20 minute periods immediately before and after addition of toxin-free medium $(A)$ or toxin-containing medium $(B)$

\begin{tabular}{|c|c|c|c|c|c|c|c|c|}
\hline & \multicolumn{3}{|l|}{$\mathrm{Na}$} & \multicolumn{3}{|l|}{$\mathrm{Cl}$} & \multirow[b]{2}{*}{ Isc } & \multirow[b]{2}{*}{$J^{R} \mathrm{Net}$} \\
\hline & $m s$ & $s m$ & $\mathrm{Net}$ & $m s$ & $s m$ & Net & & \\
\hline \multirow{8}{*}{$\begin{array}{l}\text { A Control }(n=6) \\
\text { Toxin-free medium } \\
(80-100 \text { min }) \\
\text { B Control }(n=7) \\
\text { Toxin-containing } \\
\text { medium } \\
(40-60 \text { mins })\end{array}$} & $17 \cdot 56 \pm 1 \cdot 80$ & $11 \cdot 78 \pm 1 \cdot 41$ & $+5 \cdot 78 \pm 0 \cdot 85$ & $11 \cdot 87 \pm 1 \cdot 22$ & $9.69 \pm 0.68$ & $+2 \cdot 18 \pm 0 \cdot 74$ & $4.59 \pm 0.76$ & $+1.00 \pm 0.77$ \\
\hline & $14.43 \pm 0.90$ & $10 \cdot 34 \pm 0 \cdot 58$ & $+4 \cdot 35 \pm 0.58$ & $10.05 \pm 0.99$ & $8.85 \pm 0.73$ & $+1 \cdot 20 \pm 0.65$ & $5 \cdot 81 \pm 0 \cdot 60$ & $+3.41 \pm 0.20$ \\
\hline & & NS & & & NS & & $\mathrm{p}<0.01$ & \\
\hline & $14 \cdot 00 \pm 0 \cdot 88$ & $9.71 \pm 0.94$ & $+4 \cdot 36 \pm 0.75$ & $10 \cdot 88 \pm 0.62$ & $10 \cdot 63 \pm 1 \cdot 18$ & $+0.26 \pm 1.04$ & $3.52 \pm 0.42$ & $-0.57 \pm 0.22$ \\
\hline & & & & & & & & \\
\hline & $11 \cdot 48 \pm 1 \cdot 34$ & $10 \cdot 81 \pm 1 \cdot 18$ & $+1 \cdot 21 \pm 1 \cdot 26$ & $11 \cdot 16 \pm 0 \cdot 51$ & $12 \cdot 54 \pm 1 \cdot 13$ & $-1 \cdot 39 \pm 1 \cdot 24$ & $4 \cdot 32 \pm 0 \cdot 72$ & $+0.94 \pm 0.55$ \\
\hline & NS & NS & $p<0.05$ & NS & $p<0.05$ & & NS & \\
\hline & $10 \cdot 72 \pm 0.96$ & $10 \cdot 50 \pm 0.91$ & $+0.29 \pm 1.41$ & $10 \cdot 21 \pm 0.97$ & $12 \cdot 90 \pm 1 \cdot 10$ & $-2.43 \pm 0.98$ & $4 \cdot 80 \pm 0.42$ & $+0.35 \pm 1.41$ \\
\hline$(80-100$ mins $)$ & $\mathrm{p}<0 \cdot() 2$ & NS & $p<0.01$ & NS & $p<0.05$ & $p<0.01$ & $\mathrm{p}<0.01$ & NS \\
\hline
\end{tabular}

All fluxes cxpressed as $\mu \mathrm{Eq} \mathrm{cm}{ }^{-2} \mathrm{~h}^{-1}$. $\mathrm{ms}=$ mucosa to serosa flux, $\mathrm{sm}=$ serosa to mucosa flux. + values signify absorption, - values signify secretion. $p$ values refer to significance of difference from its control.

confirmed that all the significant flux responses to the toxin were significantly different from the toxin-free medium responses.

With a calcium-free buffer solution on the serosal side the inhibition of net sodium absorption and the net chloride secretion induced by the toxin was markedly reduced (Table 2 ). The addition of theophylline $10^{-2} \mathrm{M}$ to the calcium-free serosal reservoir after 100 minutes' incubation with toxin induced a sharp rise in short circuit current $(22.3 \%$ in two minutes, $p<0 \cdot 01)$ confirming viability of the ileal tissue $(n=3)$.

\section{CYCLIC NUCLEOTIDE STUDIES}

$\mathrm{Cl}$ difficile toxin incubated for periods of up to 90 minutes with segments of stripped rabbit ileum had no effect on mucosal cAMP concentrations when compared with control tissues (Table 3 ) at a time when flux changes due to the toxin were observable. The ability of tissues incubated in this way to respond to cAMP stimulating agents was confirmed with prostaglandin $\mathrm{E}_{2}\left(10^{-4} \mathrm{M}\right)^{3 / 3}$ which produced a two-fold rise in cAMP concentration after 45 minutes (Table 3 ).

Similar results were obtained when the toxin was incubated directly with a plasma membrane rich fraction prepared from isolated rabbit epithelial cells. Production of cAMP under control conditions increased linearly up to 30 minutes followed by a gradual 'levelling-off' over the final 30 minutes' incubation. Assays which included toxin closely followed this pattern with no statistically significant effect on cAMP generation $(n=5)$ at a time when flux changes due to the toxin were observable. There was also no evidence for the involvement of cGMP in the action of this toxin. The time course of cGMP production in membranes was identical for both toxin-containing and control media $(n=5)$. The responsiveness of the membrane preparation to stimulation was assessed for adenylate cyclase with VIP and guanylate cyclase with heat stable $E$. coil enterotoxin. ${ }^{14}$ In both instances marked stimulation occurred.

Histological examination by light microscopy showed that the tissue was undamaged after two hours' incubation (Figure).

\section{Discussion}

Antibiotic-associated colitis is now recognised to be

Table 2 Unidirectional and net Na and (l fluxes over 20 minute periods immediately before and 80 to 100 minutes after addition of toxin-containing medium utilising $\mathrm{Ca}^{2}{ }^{+}$free medium serosally.

\begin{tabular}{|c|c|c|c|c|c|c|c|c|c|}
\hline \multirow[b]{2}{*}{ - } & \multicolumn{3}{|l|}{$\mathrm{Na}$} & \multicolumn{3}{|l|}{ Cl } & \multirow[b]{2}{*}{ Isc } & \multirow[b]{2}{*}{$J^{R} N e t$} & \multirow[b]{2}{*}{$R$} \\
\hline & $m s$ & $s m$ & Net & $m s$ & $s m$ & Net & & & \\
\hline $\begin{array}{l}\left.\text { Control (C } a^{2} \cdot \text { frec }\right) \\
(n=6)\end{array}$ & $14 \cdot 72 \pm 1 \cdot 23$ & $8 \cdot 22 \pm 0 \cdot 86$ & $+6.52 \pm(0.71$ & $11.46 \pm(1.94$ & $8 \cdot 8.5 \pm(1) \cdot 62$ & $+2 \cdot 61 \pm(1) \cdot 46$ & $3 \cdot 71 \pm 0 \cdot 23$ & $-0 \cdot 19 \pm 0 \cdot 65$ & $28 \cdot 6 \pm 1 \cdot 50$ \\
\hline Toxin $\left(C a^{2} \cdot f r e c\right)$ & $\begin{array}{l}12 \cdot 81 \pm 1 \cdot 52 \\
p<(1) \cdot(15\end{array}$ & $\begin{array}{l}7 \cdot 5.5 \pm(1) \cdot 83 \\
\text { NS }\end{array}$ & $\begin{array}{l}+4 \cdot 6 \pm 1 \cdot 30 \\
\text { NS }\end{array}$ & $\begin{array}{l}1(1 \cdot 39 \pm(1) \cdot 72 \\
\text { NS }\end{array}$ & $\begin{array}{l}8.96 \pm(1.71 \\
\text { NS }\end{array}$ & $\begin{array}{l}+1.4 .3 \pm(1) \cdot 49 \\
\text { NS }\end{array}$ & $\begin{array}{l}3 \cdot 75 \pm(1 \cdot 42 \\
\text { NS }\end{array}$ & $\begin{array}{l}+() \cdot 36 \pm 1 \cdot 40 \\
\mathrm{NS}\end{array}$ & $\begin{array}{l}33 \cdot 1 \pm 3 \cdot(10 \\
\mathrm{NS}\end{array}$ \\
\hline
\end{tabular}

Mean tissue resistance ( $R$ ) expressed in ohms $\mathrm{cm}^{2}(\mathrm{n}=12)$. 
Table 3 cAMP concentration in mucosal pieces $(n=9)$

\begin{tabular}{lcc}
\hline & 45 minute & 90 minute \\
\hline Control medium $(200 \mu \mathrm{l})$ & $5.47 \pm 0.89$ & $4.82 \pm 0.51$ \\
Control medium + toxin $(200 \mu \mathrm{l})$ & $5.01 \pm 0.63$ & $4.59 \pm 0.577$ \\
$\mathrm{PGE}_{2}\left(10^{-4} \mathrm{M}\right)$ & $11.72 \pm 1.72^{*}$ & - \\
\hline
\end{tabular}

${ }^{*} \mathrm{p}<0 \cdot 01$

caused by $\mathrm{Cl}$ difficile toxin. It is usually associated with damage to the colonic mucosa giving rise to the characteristic sigmoidoscopic appearances. ${ }^{3}$ These cytotoxic effects of the toxin have been shown in tissue culture. ${ }^{47}$ The clinical picture, however, is often one of watery diarrhoea without bleeding, commonly without visible mucosal damage ${ }^{5}$ and this is consistent with the idea that the toxin can provoke diarrhoea in the absence of mucosal damage, perhaps by acting as a secretogogue. In our study we have used a crude extract which probably contains both an enterotoxin and a cytotoxin. This crude $\mathrm{Cl}$ difficile toxin did, indeed, stimulate chloride secretion and reduced sodium absorption in isolated rabbit ileum. The observations that the ion flux responses to the toxin were selective and were abolished by removal of calcium from the serosal bathing medium suggest that the toxin activated a specific secretory process rather than simply exerting a non-specific damaging effect. The absence of histological evidence of tissue damage also tends to support this conclusion.

The observation that our control medium had similar electrical effects to the toxin suggests that they were mainly because of components of the culture medium. The ionic basis for the electrical response is unclear; certainly no significant effects on $\mathrm{Na}$ and $\mathrm{Cl}$ fluxes were observed with control medium.

The cyclic nucleotide studies failed to reveal evidence for an action involving cAMP, adenylate cyclase, or guanylate cyclase and thus the action of this toxin is distinct from that of other toxins including cholera toxin, and $E$. coli heat labile toxin which activate adenylate cyclase ${ }^{1315}$ and of $E$. coli heat stable toxin which activates guanylate cyclase. ${ }^{14}$ Vesely and co-workers ${ }^{16}$ recently showed that $\mathrm{Cl}$ difficile cytotoxin stimulated guanylate cyclase activity in cultured hamster fibroblasts and in hamster ileum and caecum. In these experiments, however, adenylate cyclase activity was stimulated in the supernatant obtained from homogenising whole gut tissue. Cyclase activity in the pellet fraction, presumably containing plasma membranes, was not stimulated in these experiments. Our studies were performed on purified plasma membrane fractions of epithelial cells, the site of the transport cyclases. It seems likely, therefore, that the guanylate cyclase activity stimulated in hamster ileum and caecum was that normally located in other sites, possibly the muscle coats and serosa.

The inhibition of toxin-mediated secretion, by removal of calcium from the serosal bathing medium, suggests that extracellular calcium is required for full activity of the toxin. The response to theophylline after toxin exposure in calcium-
Figure Well-preserved mucosa brush border of stripped rabbit ileum after 100 minutes' incubation with $\mathrm{Cl}$ difficile toxin (light micrograph, on $g$. magnification $\times 1500$.)

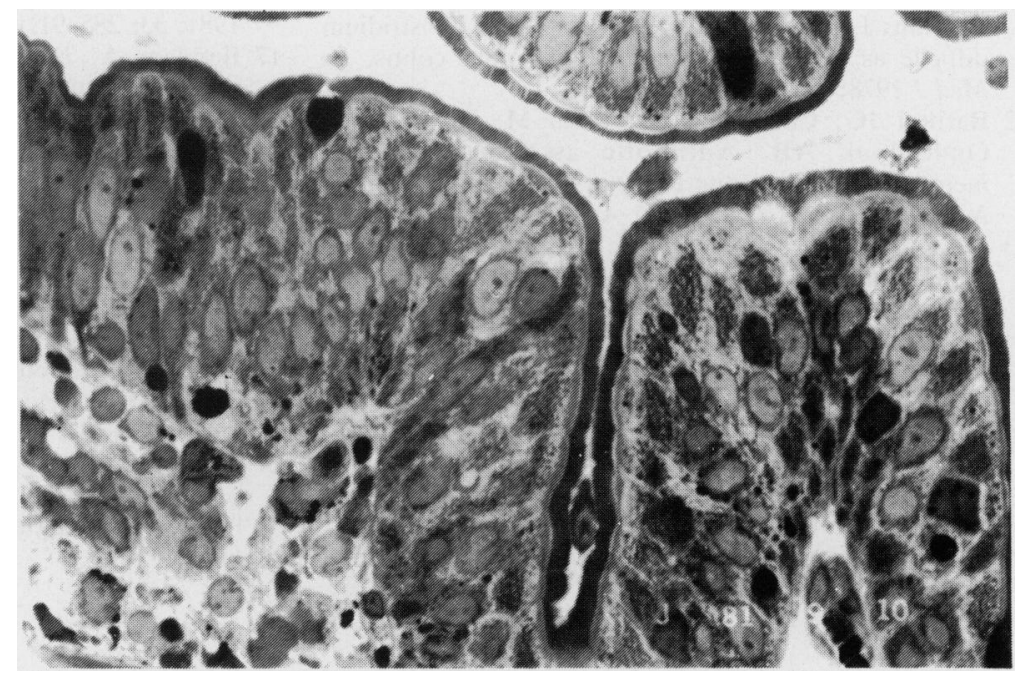


deprived tissues confirms their viability and potential to respond to other stimuli. The mechanism for the action of calcium in controlling intestinal secretion is unclear but the involvement of a calcium-dependent regulator protein (calmodulin) has been proposed. ${ }^{17}$ Furthermore, work recently reported in an abstract implicates calcium in the control of a neutral $\mathrm{NaCl}$ brush border uptake process. ${ }^{18}$ Our data are not incompatible with such an involvement of calcium in toxin-induced secretion. A full description of the role of calcium must, however, await further study.

Other secretagogues which require extracellular calcium for their action include 5-hydroxy tryptamine (5 HT) ${ }^{19}$ acetylcholine, and the calcium ionophore A23187. ${ }^{20}$ It is conceivable, therefore, that $\mathrm{Cl}$ difficile toxin activates a similar calcium'gating' process. Alternatively, it may act by liberating a local mediator, such as 5 HT or acetylcholine. Although the effects of the toxin are not identical with those of $5 \mathrm{HT}$ - for example, $5 \mathrm{HT}$ decreases $\mathrm{M} \rightarrow \mathrm{S}$ chloride flux, which the toxin does not - they are sufficiently similar to invite further study.

Whatever the underlying mechanism, it seems likely that these secretory effects of $\mathrm{Cl}$ difficile toxin contribute to the diarrhoea associated with this infection.

\section{References}

1 George RH, Symonds JM, Dimock F, Brown JD, Arabi Y, Shinagawa N, Keighley MRB, AlexanderWilliams J, Burdon DW. Identification of Clostridium difficile as a cause of pseudomembranous colitis. $\mathrm{Br}$ Med J 1978; 1: 695.

2 Bartlett JG, Chang TW, Gurwith M, Gorbach SI, Onderdonk AB. Antibiotic associated pseudomembranous colitis due to toxin producing clostridia. $N$ Engl J Med 1978; 298: 531-4.

3 Keighley MRB. Antibiotic associated pseudomembranous colitis: pathogenesis and management. Drugs 1980; 20: 49-56.

4 Donta ST, Shaffer SJ. Effects of Clostridium difficile toxin on tissue-cultured cells. J Infect Dis 1980; 141: 218-22.

5 Mogg GAG, Keighley MRB, Burdon DW, AlexanderWilliams J, Youngs D, Johnson M, Bentley S, George RH. Antibiotic-associated colitis - review of 66 cases. Br J Surg 1979; 66: 738-42.

6 Giugliano LG, Mann GF, Drasar BS. Other enterotoxic enteropathies - the use of tissue culture for the detection of Clostridial toxins. Eur J Chemo Antibiotics. (In press.)

7 Taylor NS, Thorne GM, Bartlett JG. Separation of an enterotoxin from the cytotoxin of Clostridium difficile. Clin Res 1980; 28: 285A.

8 Isaacs PET, Corbett CL, Riley AK, Hawker PC, Turnberg LA. In vitro behaviour of human intestinal mucosa. The influence of acetylcholine on ion transport. J Clin Invest 1976; 58: 535-42.

9 Ussing $\mathrm{HH}$, Zerahn K. Active transport of sodium as the source of the electrical current in the short circuited isolated frog skin. Acta Physiol Scand 1951; 23: 110-27.

10 Lowry $\mathrm{OH}$, Rosebrough NJ, Farr AL, Randall RJ. Protein measurement with the folin phenol reagent. $J$ Biol Chem 1951; 193: 265-75.

11 Murer H, Ammann E, Biber J, Hopfer U. The surface membrane of the small intestinal epithelial cell (1) Localisation of adenyl cyclase. Biochim Biophys Acta 1976; 433: 509-19.

12 Amiranoff B, Laburtle M, Dupont C, Rosselin G. Characterisation of a vasoactive intestinal peptide sensitive adenylate cyclase in rat intestinal epithelial cell membrane. Biochim Biophys Acta 1978; 544: 478-81.

13 Kimberg DV, Field M, Johnson J, Henderson A, Gershon E. Stimulation of intestinal adenyl cyclase by cholera entero-toxin and prostaglandins. J Clin Invest 1971; 50: 1218-30.

14 Field M, Graf LH, Laird WJ, Smith PL. Heat stable entero-toxin of $\mathrm{E}$. coli. In vitro effects on guanylate cyclase activity, cyclic GMP concentrations and ion transport in small intestine. Proc Natl Acad Sci USA 1978; 75: 2800-4.

15 Evans DJ, Chen LC, Curlin GT, Evans DG. Stimulation of adenyl cyclase by Escherichia coli enterotoxin. Nature New Biol 1972; 236: 137-8.

16 Vesely DL, Straub KD, Nolan CM, Rolfe RD, Finegold SM, Monson TP. Purified Clostridium difficile cytotoxin stimulates guanylate cyclase activity and inhibits adenylate cyclase activity. Infect Immunol 1981; 33: 285-91.

17 Ilundain A, Naftalin RJ. Role of $\mathrm{Ca}^{2+}$-dependent regulator protein in intestinal secretion. Nature 1979; 279: $446-8$.

18 Donowitz M, Asarkof N. Intracellular calcium (Ca) is a regulator of active $\mathrm{Na}$ and $\mathrm{Cl}$ absorption in rabbit ileum. Fed Proc 1981; 40: 420.

19 Donowitz M, Asarkof N. Pike G. Serotonin-induced active ileal secretion, evidence of calcium dependence. $J$ Clin Invest 1980; 66: 342-51.

20) Bolton JE, Field M. Ca ionophore-stimulated ion secretion in rabbit ileal mucosa: relation to actions of cyclic $3^{\prime} 5^{\prime}$-AMP and carbamylcholine. J Membr Biol 1977; 35: 159-74.

21 Donowitz M, Tai YH, Asarkof N. Effect of serotonin on active electrolyte transport in rabbit ileum, gall bladder and colon. Am J Physiol 1980); 239: G463G472. 